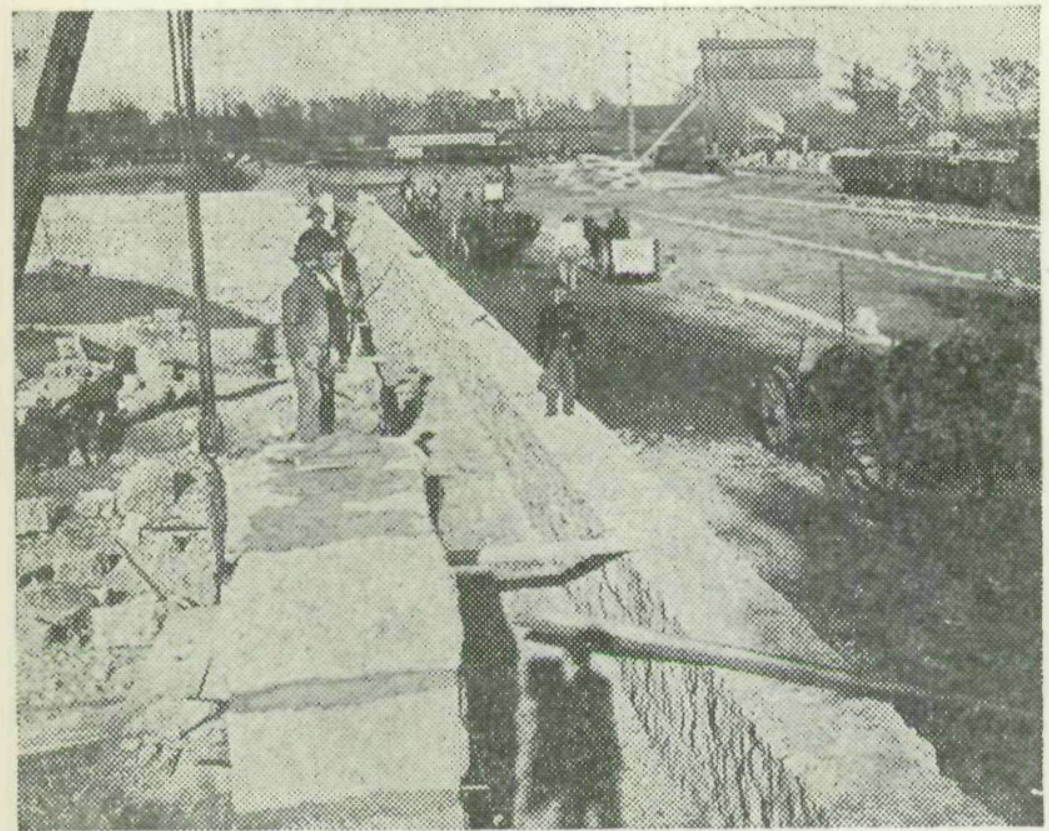

The Laying of the Foundation of the Chicago Great Western Shops in Oelwein, 1894

-Illustration by Charles Ridler of Oelwein 


\section{Oelwein Secures the Machine Shops of the Chicago Great Western Railway Company, 1894}

\section{By James Thomas Craig}

Upon locating in Oelwein last fall, and encouraged to undertake some research in local history, ${ }^{2}$ the writer soon discovered that the history of Oelwein is primarily the history of the Chicago Great Western Railway, and to a considerable extent, the Oelwein Shops of that company.

Prior to the location of the Great Western Shops almost fifty years ago, the town was typical of many another small Iowa village established in the halycon days of railroad promotion in the eighteen seventies. Founded in that decade when the Burlington, Cedar Rapids \& Minnesota built its lines through the county, Oelwein for years was largely but a farming community, notable primarily for the hard-working, thrifty, German farmers who comprised much of the township's population. The shops of the Great Western made modern Oelwein. ${ }^{3}$

In the spring of 1894 the businessmen of Oelwein arranged to furnish the land for the railroad's machine and repair shops and yards and also the funds for constructing the shop buildings and purchasing of part of the new machinery to be installed therein. However, the building of the Oelwein Shops was delayed by the general business and industrial depression which followed the financial panic of 1893. Then only with the help of English capital and the boom in business accompanying the War with Spain was it possible to complete the shops. In the spring of 1898 work on the unfinished foundations was

\footnotetext{
${ }^{1}$ This article is substantially the same as the paper read by the writer before the Oelwein Rotary Club, Oelwein, Iowa, Aug. 10, 1942. It was published in The Oelwein Daily Register, Aug. 13-21, 1942. It is the first of a series of articles which the author plans to prepare and have published concerning Oelwein and the Chicago Great Western Railway Company. The research for this article was done during the spring and summer months of 1942, at which time Mr. Craig was employed by the Independent School Distriet of Oelwein as a teacher of history in the senior high school.

${ }^{2}$ By Walter H. Beall, vice president, Iowa Association of Local Historical Societies, and Kenneth E. Colton, Iowa State Department of History and Archives. ${ }^{3}$ George W. Fitch, Past and Present of Fayette County, Iovoa, (B. F. Bowen \& Co., Indianapolis, Ind., 1919, 2 vols.) $1: 419-420$.
} 
resumed. In May of the following year the shops were completed and put into operation. The formal dedication of the Oelwein Shops took place Thursday, September 28, 1899. The growth of Oelwein from a mere village of eight hundred people in 1890 to a town of 1928 persons five years later, and to a modern city of 7801 inhabitants in 1940 is due principally to the Oelwein Shops. In many ways Oelwein has benefited by the shops. The securing of these shops forty-eight years ago forms this history. ${ }^{4}$

In 1886 the Minnesota \& Northwestern Railroad, the parent company of the "Great Western," erected repair shops at South Park, Minnesota, a suburb of St. Paul. At the time this was a good location for the shops, as the railroad extended from St. Paul southward into northeastern Iowa. That year the line was built through Oelwein to Dubuque, and in the following year the property was taken over by the Chicago, St. Paul \& Kansas City Railroad. This company immediately preceded the Chicago Great Western Railway Company. By 1888 the C. St. P. \& K. C. operated a through line between St. Paul and Chicago, and two years later a branch line extending from Oelwein through Des Moines and St. Joseph to Kansas City was put into operation. By this time it was evident that the South Park Shops were poorly situated and could not serve adequately the enlarged system. Yet, the shops were not moved from South Park. They had cost approximately three hundred thousand dollars and the C. St. P. \& K. C. was then simply financially unable to build new shops elsewhere. ${ }^{5}$

On January 11, 1892, the newly organized Chicago Great Western Railway Company took over the property of the bankrupt C. St. P. \& K. C. Railroad. The new directors were anxious to transfer the shops to some point more centrally located along the line. Elma, Sumner,

"Fred S. Robinson, "Oelwein, Iowa," in The Maize, 3:47; Earl E. Deyo, letter to B. F. Parsons, Oct. 29, 1941, ms.; Oelwein was incorporated as a city in 1897; Deyo, op. cit.; Rand McNally \& Co., Reference Map of Iowa, 1941, p. 26. "Deyo, "History of the C. G. W. Ry." in The Oelwein Daily Register, July 10, 1939; Deyo, "Remarks before Oelwein Businessmen," Nov. 3, 1941; Deyo, Notebook, n. p., ms.; address to Oelwein eitizens by President A. B. Stickney, June 2, 1894, cf. The Saint Paul Pioneer Press, June 3, 1894; The Oelwein Register, June 7. 1894; The Oelwein Register, May 3, 1894. Cf. George W. Fitch, Past and Present of Fayette County, Iowa, (B. F. Bowen \& Co., Indianapolis, 1910, 2 vols.) $1: 138,420-421$. 
Oelwein or Dubuque, they felt, would be much more suitable than South Park. They were eager to eliminate the expense of hauling broken-down or wrecked rolling stock or motive power from Chicago or Kansas City three or four hundred miles to South Park for repairs. It was then costing the company three-fourths of a cent to haul an empty freight car one mile. With the financial panic of 1893 demanding retrenchment, the directors were desperate. To partially relieve the situation they ordered more repair and rebuilding work at the Oelwein Roundhouse. The offices of the assistant general superintendent and the master mechanic for the entire system were changed from St. Paul to Oelwein at the same time. ${ }^{6}$

As a general economy move following the panic of 1893 many large manufacturing concerns moved their factories to smaller towns located at considerable distances from the large cities. It was believed that this would result in the obtaining of cheaper labor and that less money would be lost in labor disputes. The "Great Western" was not bothered with strikes at its South Park Shops, but the Great Northern Railroad was experiencing labor trouble at its St. Paul shops. The "Great Western" officials possibly feared that should the strike spread to their shops they could not survive the financial setback. A strike did occur on the "Great Western" June 29, 1894, not at South Park but in Oelwein among the roundhouse employees and section men. This, however, was not a serious strike and consequently did not last long. No strike of any importance occurred at the South Park Shops until April 13, 1899, at the time the Oelwein Shops were nearly ready for occupancy. ${ }^{7}$

As the depression became more pronounced during the second half of 1893, "Great Western" officials took additional steps in the hope of effecting economies. Most important of all was their announcement that Oelwein was soon to become the operating center of the entire system. The businessmen of this town assumed that

\footnotetext{
${ }^{\circ}$ C. G. W. Ry. Co. Corporation Records, 1:1-6, ms,; The Oelwein Register, Jan. 11, May 3, June 7, 1894; The Saint Paul Pioneer Press, June 3, 1894.

${ }^{7}$ The Saint Paul Pioneer Press, Apr. 19-May 2, 1894; The St. Paul Dispateh, June 30, 1894; Apr. 13, 15, 17, 1899.
} 
Oelwein was eventually to become the "repairing and rebuilding" center as well! Early in January, 1894, A. E. Woodruff, editor of The Oelwein Register, announced that he understood the railway officials were contemplating the establishment of "extensive repair shops" at Oelwein at a very early date! This marks the beginning of the agitation by which Oelwein secured the shops of the "Great Western" in April, $1894 !^{8}$

Although at the present writing it is not known for sure, it is thought that A. B. Stickney, ${ }^{9}$ chairman of the executive committee of the directors of the "Great Western," and soon to be their president, got in touch with an experienced and well-known railroad land promoter by the name of E. F. House, then of New York City. And, a man whose name was the important thing was engaged. ${ }^{10}$ This was Judge R. N. Baylies, then of Chicago, but formerly of Des Moines. These two men were to proposition the residents of Elma, Sumner, Oelwein, and Dubuque, each of which was located on the main line of the "Great Western" in northeastern Iowa. Wherever the townspeople agreed to donate not only the land for new shops and yards, but also contribute two hundred thousand dollars toward the erection of the new buildings and the purchase of some of the new machinery, Stickney would agree, on behalf of the directors, to remove the principal machine and repair shops of the railway company to that place. Because a branch line to Kansas City then left the main line at Oelwein, and another branch line extending from Oelwein to Sioux City and Omaha was contemplated, it was decided to proposition the businessmen of Oelwein first. ${ }^{11}$

The Oelwein Register, June 22, July 27, Sept. 14, 1893 ; Jan. 11, 1894.

The Biographical Directory of the Railway Officials of America, 1893 edition, 3:354: "STICKNEY ALPHEUS BEEDE. Born June 27, 1840, at Wilton, N. H. Entered railway service in 1871, since which time he has been consecutively vice-president, general manager, attorney, etc., St. Paul, Stillwater \& Taylor Falls Ry. for several years; superintendent construction, St. Paul, Minneapolis \& Manitoba Ry.; 1880-1, general superintendent, Canadian Pacific Ry.; 1882, vice-president, Minneapolis \& St. Louis Ry.; also built Minnesota Central Ry.; 1884, president, Minnesota \& Northwestern Ry. until consolidated with Chicago, St. Paul \& Kansas City, when he became president latter road, holding that office until 1890, when he became chairman, board of directors, which position he now holds. Compiled and edited by T. A. Busbey. Published by The Railuay Age, Chicago.

10Thomas Smith, statement to author, Aug. 1, 1942.

${ }^{11}$ The Oelwein Register, Apr. 7, May 3, 1894. 
During March, 1894, the plan was completed. House and Baylies were to go to Oelwein and let it be known that the "Great Western" officials were anxious to establish the shops at Oelwein, but to do so would require the abandonment of the shops at South Park. If the people of Oelwein would furnish the land and funds already referred to, the directors would locate new shops in Oelwein. The idea was to secure options to purchase at least a thousand acres of land adjoining the town $;^{12}$ the options to be obtained at current land values. The options were to terminate at the end of a year. A land company was to be formed to which the options would be assigned. With the erection of the shops and their operation, and other manufacturing establishments which, it was figured, would be attracted to Oelwein, the value of the optioned land would undoubtedly increase. The profit made from the sale of this land could then be used to pay for the land donated for the shops and yards, and, in addition, provide the funds required for the construction of the new buildings and machinery. Before any land was sold the railway officials were to select the site for the new shops. They were also to draw the plans of the new buildings and supervise their erection. In this way, it was thought, Oelwein might secure the shops of the "Great Western" without any great outlay of money. It was taken for granted that the people of Oelwein would foresee the benefits which would result from the building of the Oelwein Shops. ${ }^{13}$

With the plan well in mind House and Baylies arrived in Oelwein Wednesday morning, March 28, 1894, and spent the day explaining the plan to several of the businessmen. During the afternoon handbills were distributed announcing a meeting that evening of everyone interested. At the meeting over one hundred fifty business and professional men appeared. John Jamison, of the State Bank of Oelwein, was asked to preside. He stated the purpose of the meeting and then introduced

\footnotetext{
122,000 acres, according to The Manchester Press, Apr. 11, 1894, quoted in The Oelwein Register, Apr. 19, 1894.

1sThe Oelwein Register, Apr. 7, May 3, 1894.
} 
Judge Baylies who, according to The Oelwein Register, in a "plain straightforward manner, which at once won the confidence of those present," explained the plan in detail. The plan was approved and Jamison was asked to secure the options. He appointed several men to a committee and instructed them to call upon the farmers owning the land surrounding the town. Fully cognizant of the significance of the undertaking to Oelwein's future prosperity, those appointed agreed to donate their time and personally go after the options. Most of them began soliciting the very next morning and continued until Friday morning, April 6, at which time it was announced that they had secured options on sufficient land. The majority of the landowners approached readily granted options on their lands; some refused, not that they wanted to keep the shops out of Oelwein, but because they were unwilling to give options on lands they had planned to occupy permanently. ${ }^{14}$

On Monday afternoon, April 2, it was decided to call another meeting of the public that evening so that everyone might know what progress had been made in the obtaining of the options. The meeting was held in what was reported to be "Winder's Opera House;" but contemporaries recall that it was not an opera house, but rather a three-story brick building on the west side of South Frederick Avenue where Thiele's Grocery is now located. John Winder had built the structure prior to 1894 and it was consequently known as the "Winder Building." The meeting referred to was undoubtedly held on the second floor as the first floor was occupied by business houses and the third, as private dwellings. ${ }^{15}$

At the meeting it was reported that Gustavus A. Oelwein, Sr., had held the "key to the whole situation." $\mathrm{He}$ owned considerable acreage on two sides of the town and for the preceding three days it had been feared that he would not see his way clear to make what he felt would be a sacrifice. Oelwein then owned practically all of the

\footnotetext{
14Tbid., Apr. 7, 1894.

15 Ibid., Bert L. Belt and Thomas Smith, statements to the author, July 28, Aug. 1, 1942.
} 
land in the southwest part of town from the intersection of Charles Street and 1st Avenue S. W. with the exception of that owned by George N. Armstrong. It seems that everyone of any importance, including old Dr. Israel Pattison, ${ }^{16}$ had been asked to talk to "Gus" in the hopes of influencing him to grant the option. ${ }^{17}$

As late as Monday afternoon, April 2, Oelwein had not granted the option on his land. Jamison called together at the State Bank of Oelwein at seven o'clock the men who had been assigned to secure Oelwein's option. Ray B. Phillips declared that the real reason why Oelwein refused for so long to grant the option was because of his distrust of Jamison or of anything that the latter was connected with. Phillips stated that prior to 1894 Jamison had attempted to take over some of Oelwein's property. The dispute was settled in the District Court at West Union, where Oelwein was sustained. Since then he had hated Jamison intensely. Phillips' assertion was evidently correct for when the men decided to go once more to Oelwein, Jamison did not accompany them. Upon their arrival at the Oelwein residence the men were asked by Oelwein: "Where's Jamison?" The fact that the banker was not along resulted in Oelwein's willingness to discuss the matter. After an hour or so of propositioning he acquiesced and granted the option. His main reservation was readily granted. This was that Oakdale Cemetery, situated northwest of the old roundhouse and in which he had an interest, was not to be disturbed. Oelwein's land was later purchased for the site of the shops and yards and he was paid thirteen thousand dollars. Another contemporary landholder whose land, lying north of Oelwein's land, was optioned but not purchased, recently declared: "This was an awful lot of money in those days to pay for just a hog pasture with a creek meandering through it!"18

After obtaining the option on Oelwein's land the solici-

\footnotetext{
16The first mayor of Oelwein and for many years physician and surgeon for the C. G. W. Ry. Co., Fitch, op. cit., 2:773-776.

${ }^{17}$ The Oelwein Register, Apr. 7, 1894; Thomas Smith, op. eit.

18Ray B. Phillips, statement to author Aug. 1, 1942; Thomas Smith, op. eit.
} 
tors hurried to the general meeting and announced their success. Everyone present thought the plan would succeed. To quote the reporter: $:^{19}$

The opera house was packed with interested citizens of the town, and as one man they gave three rousing cheers for the man whose action meant so much for the future advancement of our thriving little city. ... Mr. Oelwein was too much interested in the permanent welfare of the town which bears his name.

George N. Armstrong, and others, who likewise had granted options on large tracts of land, were "loudly cheered!" At first Armstrong had held out just as had Oelwein, "but," to quote a contemporary, "he was sweetened up by the promoters of the land company and soon fell in line with them."20

After all those soliciting options had reported on their progress House announced that fifteen hundred dollars was needed "to assist in defraying further preliminary work." He could have easily raised this amount then and there had he accepted large contributions from individual businessmen. However, he declined to accept more than ten dollars from any one person. In this way, he said, the undertaking would be more of a community affair. Only a little over a third of the desired amount was raised so he appointed several committees to secure the remainder. The full amount was raised by the following Friday. ${ }^{21}$

The same night the second general meeting was held, House and Jamison, accompanied by H. C. Sturgis of the Citizens' State Bank, took the early morning train to St. Paul. ${ }^{22}$ The next morning they explained to Stickney and other "Great Western" directors what had taken place. Stickney was elated and suggested that the land company be organized and the contract between it and the railway company be drawn up and signed. Jamison and Sturgis returned to Oelwein Tuesday night asserting that they were "more than ever satisfied with the prospects of the plan succeeding." House remained in St. Paul over Wednesday to work out, with Stickney and other officials,

${ }^{10}$ The Oelwein Register, Apr. 7, 1942.

oRichard H. Smith, statement to author, Aug. 1, 1942.

21 The Oelwein Register, op. cit.

2This was Train No. 1, the "Chicago \& St. Paul Limited," ef. The Oelwein Register, Nov. 16, 1893. 
articles of incorporation for the Oelwein Land Company and the contract by which the shops would be assured to Oelwein. ${ }^{23}$

The Oelwein Land Company, as organized in the general offices of the Chicago Great Western Railway Company in St. Paul, April 4, 1894, consisted of the following five men: Judge Baylies, House, Jamison, Arnold Kalman and Ansel Oppenheim. The latter two were directors of the "Great Western" and it was thought advisable to have them also serve as directors of the land company. Baylies, House and Jamison were also named to the first board of directors. For the first year the five directors elected the following officers from among their own number: Judge Baylies, president; House, first vice-president and general manager; Kalman, second vicepresident; and Jamison, secretary-treasurer. The incorporation was to last twenty years; the articles of incorporation being filed with the Fayette County clerk in West Union Friday, April 6, and with the Secretary of the State of Iowa, Des Moines, the next morning. ${ }^{24}$

As stated in the articles of incorporation the Oelwein Land Company was organized for the purpose of buying up the optioned land, platting of this into town lots and selling these, and the exchange of real estate in general. The company was capitalized at twenty thousand dollars-two hundred shares at one hundred dollars each. The company's indebtedness was not to exceed two-thirds of its capital stock and private property was exempted from corporate debts. ${ }^{25}$

Special certificates for the ownership of stock in the land company were not printed. Instead, a blank form was used in which the name of the company, the name of the person to whom the certificate was issued, the number of shares purchased, and the names of VicePresident House and Secretary Jamison were written in with pen and ink. The corporate seal was affixed to each certificate in the lower left-hand corner. Many of these

${ }^{29}$ The Oelwein Register, Apr. 7, 1894.

2Ibid., Apr. 7, 26, 1894; C. G. W. Ry. Co. Second Annual Report, June 30, 1894, p. 3, Pioneer Press, St. Paul.

${ }^{25}$ The Oelwein Register, Apr. 19, July 28, 1894. 
certificates are still in the hands of the original purchasers. ${ }^{26}$

Immediately following the organization of the Oelwein Land Company, House set up for business with offices in the Jamison Building. To secure ready cash with which to purchase desired portions of the optioned land, he approached the business and professional men with the request that they loan the land company twenty thousand dollars. Twenty notes, each for a thousand dollars, were distributed among as many business firms with the idea of obtaining as many signatures to each note as possible. House promised that, as proper security, each person signing a note would be guaranteed a proportionate amount of town lots when the optioned land had been bought and platted off. To be specific: James Oelberg, then in the shoe business on South Frederick Avenue ${ }^{27}$ with James and Oscar Humphrey, signed a note along with the Humphreys and the Schneider Brothers, Lon and $\mathrm{Al}$. It was understood that each would be responsible for two hundred dollars. However, Oelberg furnished six hundred dollars because of his liability for his partners. Eventually he was given six lots scattered over town. He recalls that he sold the lots as soon as possible for they were not valuable sites. ${ }^{28}$

Richard H. Smith remembers that, as contemporary grocers, he and his brother Thomas, were asked to loan one hundred fifty dollars to the land company. They suspicioned that other merchants were not making similar loans and when approached by John Nancolas ${ }^{29}$ loaned but half the amount asked for. ${ }^{30}$

As soon as he had the cash House began buying up the optioned land. The first land to be purchased and platted into town lots was the Oelwein Land Company Addition in the northeast part of town. This was a continuation of Fairview Heights and lay north of Wing's 1st and

s0 Oelwein Land Company's "Certificate of Stock Ownership, No. 18," Apr. 25, 1895, issued to Thomas Smith.

quocation at present occupied by “The Grill," 11 S. Frederick Ave.

${ }^{28}$ The Oelwein Register, Apr. 26, 1894; James Oelberg, Thomas \& Richard H. Smith, statements to author, Aug. 1, 1942.

${ }^{\circ}$ Collector for the Oelwein Land Company.

soRichard H. Smith, op. cit. 
2d Additions. Specifically, the new addition was bounded on the west by Frederick Avenue, on the south by 6th Street N. E., on the east by 8th Avenue N. E., and on the north by 9 th Street N. E. Within two weeks B. F. Little and his assistants were reported as having platted eightysix acres. And, it was not long until lots were laid out in the Armstrong Addition in the southwest part of town and in the Iowa Development Company Addition in the northwest section. The Iowa Development Company was a subsidiary of the Oelwein Land Company, just as was D. McDonald, Stewart \& Co., realtors. The latter firm was a Chicago concern which was invited by House to assist in the sale of the lots. Representatives of this firm arrived in Oelwein the third week of April and set up for business in the Wachtel Building on the northeast corner of Frederick Avenue and Charles Street. ${ }^{31}$

When he learned, on Friday, April 6, that all the required options and funds had been obtained and that the land company had been organized and the contract drawn, the editor of The Oelwein Register decided that all this deserved a special edition. At that time Oelwein's two newspapers, The Oelwein Register and The Oelwein Record, were weeklies. Woodruff and his staff worked all that afternoon and most of the night so that they might publish the extra edition the following morning. Front-page headlines proclaimed: "OELWEIN HAS SECURED THE MACHINE SHOPS! NOW CROW! THE LONG-ANTICIPATED AND HOPED-FOR EVENT HAS TRANSPIRED!" Woodruff predicted the shops would be built southwest of the roundhouse (the roundhouse was then located at the juncture of the lines coming in from Des Moines and Dubuque; southeast of Oakdale Cemetery ${ }^{32}$ ) or northwest of the Iowa Normal Building. ${ }^{33} \mathrm{He}$ said that surveyors were to arrive the following

${ }^{31}$ The Oelwein Register, Apr. 19, 26, 1894; Thomas Smith, op. eit. Cf. plats of Oelwein in the real estate offices of Bert L. Belt and Smith Brothers, Oelwein, Iowa.

åThe Oelwein Register, Jan. 11, 1894.

s:The first grading for what was believed to be the site of the shops was done northwest of the Iowa Normal Building. This work was begun June 13, 1894, under contract by William Bentley. Clearing of the land for the actual shops' site did not begin until June 17, 1895, following a reorganization of the Oelwein Land Co. By July 4, following, two trenches for the foundation of the 
week. In particular he endeavored to point out in his special edition what the shops would mean for Oelwein. In part he wrote:

These shops are to cover a large amount of ground, fully fifteen acres, and will cost in the neighborhood of $\$ 375,000$, giving steady employment to about 350 to 500 hands. These men will be mostly skilled mechanics; men who will command good wages, and it means a pay roll of many thousand dollars to be expended among our businessmen annually. Property of all kinds will be enhanced in value; our streets will be improved; the city will be lighted with electricity; and other modern improvements inaugurated ... Oelwein is sure to be a city of several thousand in a few years. The promoters of the scheme claim that there will be a town of 15,000 here inside of three years.

He quoted statistics showing how much the "Great Western" had expended at its shops in South Park during 1893. He declared that "a vast army of workers" would be required to handle the work of the new shops in Oelwein. In his eager anticipation he erred in saying: "We do not have to wait for a long series of years before we begin to see developments. According to the terms of the contract . . . the machine shops must be completed by August 1, 1894." The terms of the contract, when made public three weeks later, ${ }^{34}$ were seen not to say this. And then it would certainly have been well-nigh impossible to have completed the shops within a four months' period!

Somewhat in the same vein as Woodruff had written, A. B. Stickney talked some weeks later. In April, 1894, the chairman of the executive committee of the "Great Western" directors had been elected president of the railway company. Before a large audience in "Winder's Opera House" Saturday evening June 2, the head of the "Great Western" declared, in part:

Between 400 and 600 men are employed in the shops at South Park, and it is likely a thousand men will be required at Oelwein. To move the shops will mean that shop buildings sufficient

main building had been dug. Contemporaries are convinced that the first grading was done primarily to aid in the sale of the lots in the northwest section of the town. The Oelwein Register, June 14, 1894; June 20, July 4, 1895; Belt \& Smith, op. cit.

${ }^{34}$ The Oelwein Register, Apr. 26, 1894. 
to accommodate this number of men will have to be built; and, in addition, over 500 houses will have to be ready for occupancy by the time the shops are completed. Furthermore, the houses will undoubtedly have to be increased to over a thousand within a few years.

Not four months, but possibly eighteen, Stickney intimated might be required for the erection of the shops. He continued by saying:

As an element of permanent prosperity to a village or city, railway shops are superior in value to any other manufacturing establishment, inasmuch as they continue to run as long as the railway runs, which is perpetual, for although men die, the railway, like the babbling brook, "runs on forever." The work at the railway shops and its monthly disbursement of wages are continuous, but it is not so with some other manufacturing establishments.

He concluded his remarks by picturing Oelwein as a "compactly-built city with comfortable homes and beautiful parks; with a garden in the rear, a nicely-kept lawn in front extending to well-paved streets lined with shade trees, and inhabited by 10,000 happy men and women." 35

Stickney's talk was considered by House as good sales literature for the Oelwein Land Company. The president's remarks were published in pamphlet form under the title, The Growth of a City-Oelwein, Iowa. Its History and Its Possibilities. The general manager planned to distribute these pamphlets at the Iowa State Fair in Des Moines the last week in August, but they did not come off the press until the first week of September. ${ }^{36}$ They were consequently given to prospective land purchasers.

On Tuesday April 17, 1894, the contract between the Oelwein Land Company and the Chicago Great Western Railway Company was signed by Presidents Baylies and Stickney and Secretaries Jamison and Robert C. Wight, respectively. ${ }^{37}$ Although the contract reads much like the

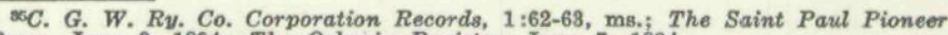
Press, June 8, 1894; The Oelwein Register, June 7, 1894.

soThe Oelwein Register, Sept. 13, 1894.

${ }^{3}$ A. B. Stickney was elected president of the C. G. W. Ry. Co. that very day. C. G. W. Ry. Co. Corporation Records, 1:62-63, ms.; St. Paul Dispatch, April 18, 1894: The St. Paul Daily Globe, Apr. 18, 1894 ; The Saint Paul Pioneer Press, Apr. $19,1894$.

On Apr. 17, 1894, House, as general manager, was reported as having signed the contract for the land company, and on Apr. 26, 1894, Judge Baylies. The
} 
original plan, which has already been described, it is of such historical significance that its terms are herein included..$^{38}$

Articles of Agreement made this 17th day of April, 1894, by and between the Chicago Great Western Railway Company, party of the first part hereinafter for convenience called the Railway Company, and the Oelwein Land Company, party of the second part, hereinafter for convenience called the Land Company.

Witnesseth: That Whereas, the Railway Company is desirous of establishing its principal repair shops at or near the Village of Oelwein, in the State of Iowa, but in order to do so requires the practical abandonment of its present shops at South Park, which have cost the Company about $\$ 300,000.00$ and the building of a new plant at Oelwein, a loss and expense which the Railway Company is unable to bear, and

Whereas E. F. House and R. N. Baylies have procurred certain options to purchase a large amount of land adjacent to said Town of Oelwein at prices believed to be its present market value with the end in view of selling the same at an enhanced value, and for the purpose of enhancing the value of said property and building up the Town of Oelwein, it is desired to secure the location of the shops of the Railway Company and it is believed that by so doing the value of said property will be so enhanced as to justify the giving of such real estate as may be required for said shops and the expenditure of $\$ 200,000.00$ in the building of the shops, tools, and appurtenances, and

Whereas said E. F. House and R. N. Baylies have assigned said "options to purchase" to the Land Company-It is therefore agreed between the parties as follows: That the Railway Company will immediately select the tract of land that will be required for the location of said shops, at, or in the vicinity of Oelwein and prepare the plans for said shops and superintend the erection of the same, and when the amount of $\$ 200,000.00$ has been expended thereon by the Land Company or its assigns, that the Railway Company will accept the transfer of the same and of the title to the land upon which the same are located, if unincumbered, and will occupy the same as machine and repair shops.

The Land Company agrees to endeavor to sell said lands and apply the proceeds:

contract stated that the "respective Presidents and Secretaries" were to affix their signatures. As copied in the C. G. W. Ry. Co. Corporation Records, the contract was not signed; but it must have been Baylies, and not House, who signed the contract on behalf of the land company. The Oelwein Register, Apr. 7, 26, 1894 ; C. G. W. Ry. Co. Corporation Records, 1:240-242; ms.

ss. G. W. Ry. Co. Corporation Records, 1:240-243, ms.; The Oelwein Register, Apr. 26, Aug. 26, 1894. 
1st. In Payment for said lands or so much thereof as it may deem best to purchase at the prices agreed upon in the options, together with the expenses of platting and selling the same.

2nd. In Payment of $\$ 200,000.00$ for the construction of said shops, yards and appurtenances according to the plans and under the supervision of the Railway Company.

3rd. Any balance shall belong exclusively to the Land Company.

And the Land Company further agrees that when it has expended said $\$ 200,000.00$ as aforesaid, it will convey said shops and the land appropriated to shop purposes to the Railway Company.

It is expressly agreed, however, that this contract shall not be binding upon the Railway Company, except at its option, unless the $\$ 200,000.00$ for the shops and its appurtenances is available either in cash or good securities by the 1st day of April, 1895.

In Testimony whereof both parties have caused these presents to be executed in duplicate and attested by the signature of their respective Presidents and Secretaries, the day and year first above written.

One term in the contract is not evident in the plan. This was the manner in which the railway directors protected themselves from incurring an additional debt. This they were especially anxious to avoid as the "Great Western" was already having its financial troubles! They expressly stated that they were not to be bound by the contract except at their own option or if the building fund was raised by the following April. This was in line with Stickney's policy of permitting no mortgage to be made on the railway property. He believed that being free of mortgages insured greater permanency. It is true that no other railroad in the United States could then boast of being free of mortgages. ${ }^{39}$

The plan of building new shops at Oelwein had been, as already pointed out, that of A. B. Stickney, chairman of the executive committee of the directors of the "Great Western." The plan did not meet with the approval of President John M. Egan, who was also the general manager. Differences of opinion on policy had existed between ${ }^{90}$ C. G. W. $R y$. Co. Corporation Records, $1: 241-242$, ms.; The Oelwein Register,
Apr. 7 , 1894. 
Stickney and Egan for the past two years, and with the unanimous approval by the directors of the contract with the Oelwein Land Company, April 17, 1894, Egan resigned. The directors accepted his resignation and immediately elected Stickney as president at an annual salary of fifteen thousand dollars. Stickney's son, Samuel C., ${ }^{40}$ was appointed acting general manager at a salary of seven hundred dollars per month. A. B. Stickney had formerly been president of the road when it was known as the Chicago, St. Paul \& Kansas City, but since 1890 had been out of that office, serving instead as chairman of the executive committee; Egan having been elected president and general manager, Samuel C. Stickney had been one of the incorporators of the "Great Western" in January, $1892 .{ }^{41}$

Egan's resignation came as a surprise to the public, but it was not only expected-it had been hoped foramong the majority of the "Great Western" directors. They wanted A. B. Stickney's leadership. They were facing a fight for their existence and they needed Stickney's aggressiveness! To gain an advantage over his competitors he was willing to be original, and if need be, unorthodox! He proved that he could overcome obstacles that would have appalled Egan. Stickney came to display a real ability in winning the confidence of investors, particularly London financiers, under the most disheartening circumstances. The directors of the "Great Western" made a wise choice in Stickney; he staged a fine up-hill fight for them. From April, 1894 on, the "Great Western" was both directed and managed by the Stickneys and it came to be a road to be reckoned with by its competitors. ${ }^{42}$

On the same day the contract between the land and railway companies was signed, April 17, 1894, twenty-

${ }^{40}$ The Biographical Directory, op. cit., 1901 ed., p. 521: "STICKNEY, SAMUEL C. Born in 1865 in Minnesota. Graduate of the Mass. Inst. of Technology. Entered railway service 1886 as locating engineer, C. St. P. \& K. C. R. R., now C. G. W. Ry., since which time he has been consecutively supt. of construction, engineer maintenance of way, asst. to president, and is now general manager of road."

${ }^{11}$ C. G. W. Ry. Co. Corporation Records, 1:62-63, 3:243-4, ms.; The Saint Paul Pioneer Press, Apr. 19, 1894; The St. Paul Daily Globe, Apr. 18, 1894 ; The St. Paul Dispatch, Apr. 18, 1894.

"2*"C. G. W. Finances," editorial, The Railway Age, $27: 146-147$. 
seven Oelwein businessmen signed a note given to Eliza M. Hanson for forty-four hundred dollars. The loan was for ninety days with interest at the rate of seven per cent. Eliza recalls that House needed this amount to buy some of the optioned land. H. C. Sturgis wrote out the note and it was witnessed by Belt \& Kint, realtors, and Sayles \& Hough, stock buyers. The men signing the note were: John Jamison, H. C. Sturgis, George H. Phillips, Charles R. Brown, A. J. Mettlin, D. M. Buzbee, Will H. Meyer, W. F. Gremmels, D. MeDonald, John H. Millard, O. A. Cummings, L. S. Hamlin, George W. Jamison, William J. Blake, John H. Kerwin, John Brett, Ben E. Hough, John C. Knapp, A. E. Woodruff, Henry V. Hoyer, John King, James Mealey, George W. Smith, John Nancolas, Nicholas Pleimling, William A. Reed, and E. L. Bucher. Five of these men are still living. ${ }^{43}$

To return to the activities of the land company. After having purchased considerable of the optioned land and having it laid out in town lots, House was anxious to hold a public sale. The day set was Monday May 28, 1894. According to the correspondent of The St. Paul Dispatch in Oelwein that day, it was "the greatest day in the history of Oelwein, or any other northern Iowa town for that matter, and the boom is now on!" Most of the business houses and many of the residences were decorated for the occasion. A large tent for the use of the land company had previously been shipped in and set up just south of Charles Street between 6th and 8th Avenues S. W. By nine o'clock many people were on the streets. A contemporary merchant declares that "at least ten thousand were here by noon." Everyone residing along the line of the "Great Western" was given free passage to come to Oelwein for the land sale. A special train from Dyersville and points between arrived at ten thirty. This train was

\footnotetext{
A. B. remained president until 1909 when the road was reorganized as the C. G. W. Railroad Co. S. C. became actual generel manager in August, 1894. and served in that eapacity until the reorganization. C. G. W. Ru. Co, Third Annual Report, June 30, 1895, p. 1; Fifteenth Annual Report, June 30, 1907, p. 3; The Oelwein Register, Ang. 16, 1894; The Oelwein Daily Register, Aug. 21, 25, 1909.

"Morrill C. Hanson, statement to author, following a telephone call to Eliza Hanson, his aunt, Aug. 1, 1942; photograph of note signed Apr. 17, 1894, gift to author from Mrs. Mary Millard Burke, Boone, Iowa; those now living are Gremmels, Hoyer, Mealey, Mettlin, and Meyer.
} 
made up of nine coaches and was "filled to the steps with probably a thousand people!" They were escorted to "the big tent of the Oelwein Land Company by fifty members of local police and firemen!"44

In order to get his news in that day's edition (The St. Paul Dispatch was an evening paper) the reporter telegraphed his story into St. Paul at noon. He stated that other special trains from Des Moines, Marshalltown, and Dubuque were scheduled to arrive soon after noon and were expected to bring thousands of prospective land buyers. The Iowa State Band was to accompany the delegation from Des Moines. "The sky is clear," he telegraphed, "and everything indicates that the great real estate sale will be a success." Nevertheless, it is the consensus today that the sale was not successful. Rather than attempt another sale, House decided to rely more on excursions by representatives of the Oelwein Board of Trade ${ }^{45}$ to towns along the line of the railway. In this way he hoped to sell large tracts of land to capitalists, manufacturers, and business firms. In addition, he planned to sell, as homesites, a considerable number of lots to shop employees at the time the shops were completed and put into operation. ${ }^{46}$

So we see the Oelwein businessmen succeeded in assuring the shops of the "Great Western" to their locality. Jamison had ably directed the work of the committees, and the railway officials, particularly Stickney, had cooperated in the matter. Due credit, of course, must be given the farmers, especially Oelwein and Armstrong, who granted options on their lands. House deserves chief credit as he had been the "prime mover" of the scheme. Although he was not the man who conceived the idea, as reported by contemporary newspapers, he undoubtedly developed the original plan according to his own way of thinking. He was a great promoter and just the man for the job ! ${ }^{47}$

\footnotetext{
"The Oelwein Register, June 14, July 12, 1894; The St. Paul Dispatch, May. 28,

1894; Oelberg and Smith Brothers, op. eit. ganized in mid-April, 1894, for the railroad promotion project, ef. The Oelwein Register, May 3, 1894.

40The Oelwein Register, July 12, 1894.

47The Oelwein Register, Apr. 7, 1894; Thomas Smith, op. cit.
} 
And now that we have the story of how Oelwein secured the shops of the "Great Western," let us enjoy the reaction of neighboring towns. This is extremely worth while for it gives us a more comprehensive picture of what was going on at the time. Sincere congratulations came at once from ten editors of northeastern Iowa. Later, best wishes came from ten other publishers. The event was noticed by such distant publications as The St. Paul Dispatch, The Saint Paul Pioneer Press, and The Des Moines News.48 Let us recall some of the congratulatory remarks. ${ }^{49}$ The Manchester Press was most cordial in declaring: "The people of Oelwein are in a position to celebrate... How great and good a thing this is for Oelwein will soon be apparent by the immense amount of business done within her limits, and to every natural impetus given to all branches of trade being carried on there." The editor of The Waverly Democrat took a practical view in saying: "Oelwein is excited over the prospects of getting the Great Western shops ... A number of Waverly people have investments in Oelwein lots, which are now beginning to soar skyward!" The Postville Graphic proclaimed: "Oelwein is in a state of great exhilaration ... The citizens are nearly beside themselves with joy, and predict a city of 15,000 in the course of a couple or three years. Well, neighbors, we are glad for your sakes, and will 'rejoice with them that do rejoice!" " The editor of The Waucoma Sentinel asserted: "Oelwein is excited over the location of the machine shops of the Great Western Railway ... Everyone in and around Oelwein is wild with delirium, and well they might!" The editor of The Allison Tribune erred just as had Woodruff in announcing that the shops were to be completed during the summer of 1894. However, the Allison editor went on to say: "The people of Oelwein are jubilant! The principal shops of the Great Western are to be located there. . . . Oelwein is to be congratulated on her good luck!" The Fredericksburg News also erred in saying

\footnotetext{
${ }^{48}$ The St. Paul Dispatch, May 28, June 5, 1894; The Saint Paul Pioneer Press, June 3, 1894; The Des Moines News, quoted in The Oelwein Register, Aug. 2, 1894, ${ }^{49}$ The following accounts from neighboring newspapers were quoted extensively in The Oelwein Register, Apr. 19, 1894.
} 
"The shops are to be completed by August 1, 1894." But, to read further: "The removal of the shops to Oelwein from St. Paul means that Oelwein is bound to be one of the best cities of Iowa." The publisher of The Charles City Intelligencer had this to say: "It is a great stroke of business on the part of the citizens of Oelwein-that thriving, busy, little city." The Jesup Critic oddly wrote: "All things come to him who waits, and as a result Oelwein is the luckiest town in this part of the State." The St. Ansgar Enterprise was brief in its comment: "We are glad to note the good luck of Oelwein." The Osage News was also brief in stating: "We hope that Oelwein may get all and even more than they expect." Other felicitations came at varying times appearing in the following publications: The Dubuque Herald, The Sumner Gazette, The Cedar Falls Gazette, The Manchester Press, The West Union Gazette, The New Hampton Courier, The Hampton Recorder, and The Jesup Critic. ${ }^{50}$

The first expression of good wishes from an individual not connected with a newspaper was by J. P. Bushnell, secretary of the Dubuque Board of Trade. During the last week of April, 1894, he visited in Oelwein and upon his return wrote the following article which appeared in The Dubuque Herald: ${ }^{51}$

\section{OELWEIN IS ON A BOOM!}

Hard times are not supposed to be productive of booms, but that does not apply to Oelwein-the enterprising town seventy miles out from Dubuque. It is probably the only place in the country at present with a well-developed case of boom on hand ... The people of Oelwein are naturally quite excited over the streak of luck, and expect to have a city of 15,000 inhabitants within three or four years. To judge from the way in which it has grown in the past half dozen years their expectations are not at all extravagant. Oelwein is a good town, well situated ... and there is no reason why it should not boom and go ahead. To say that the boom is well founded, it is enough to say that President A. B. Stickney is back of it.

Congratulations came from many sides to Oelwein in

${ }^{50}$ All of the notices appeared in The Oelwein Register of varying dates: Apr. 26, July 12, 28, 1894; July 4, Nov. 7, 1895; Nov. 5, 1896; Mar. 30, 1897.

51Reprinted in The Oelwein Register, Apr. 26, 1894. 
April, 1894, "but," wrote Woodruff, "some neighboring towns have seen fit to scoff at our thriving little city." For example, the editor of The Elma News asserted:

The Oelwein papers are making a great blow about a rumor that the Chicago Great Western shops are to be moved from St. Paul to that town. They are to be congratulated if such were true, but we are inclined to think that when the bubble is burst our neighbors will find, like the old maid, "there was nothing in it!" If the Chicago Great Western people were intending to move their shops they would not overlook Elma, the coming city of Iowa!

To this taunt Woodruff replied: "Indeed! Elma may be the coming city of Iowa, but it is so far behind the procession that it will always be coming!"52

The sarcastic attitude of The West Union Gazette reminds us of sour grapes. To quote the editor of this county-seat paper ${ }^{53}$

While we are glad that Oelwein has gained what she has so long coveted, we cannot envy her. In truth we feel a sympathy for her and a sense of self-congratulation that we are not Oelwein, and that the black smoke of machine shop engine-rooms and the bustle and rustle and roar of a railroad center are not ours. The puffing of locomotives-horrid things without cowcatchers; the clanging of steam hammers and the whooping of Saturday night revelers who have drawn their wages only to celebrate in spirits the end of a week of hard labor, will not disturb our slumbers. Our minds will not be continually distraught...W We look down from the heights upon Oelwein and watch her grow. We smile with her and are glad. Blessed be Oelwein for she shall have the shops! Blessed be West Union for she shall have them not!

Of a more fantastic nature is an article supplied The West Union Argo by its correspondent in Maynard. To quote: ${ }^{54}$

Now it came to pass, in the year 1894, in the town of Maynard, Fayette county, Iowa, a certain wise man had a dream. He seemed to gaze on a vision so dazzling that his sight for a time was dimmed. Then gradually, as his eyes became accustom-

The Oelwein Register, Apr. 19, 1894.

"sThe West Union Gazette, Apr. 12, 1894, quoted in The Oelwein Register, Apr. $19,1894$.

19. The West Union Argo, Apr. 12, 1894, quoted in The Oelwein Register, Apr. 
ed to the sight, lo! Before his astonished gaze was his sister city, Oelwein; but alas! so changed he knew her not. In the place of the two story bricks, there arose Masonic Temples too numerous to count, and the least of these was 31 stories high. And in place of the quiet village, there were the din and roar of a great city. In vain he looked for one familiar object. He sought the spot where in boyish days he dwelled with his maiden aunt, but in place of the modest cot there arose a marble mansion, and on the door-plate thereof was lettered in gold, "Mrs. Potter Palmer." Tired, heart-sick and weary he started for home, when lo? There came over the spirit of his dream a black cloud and he saw as through a mist darkly again the windy city. But alack! a day. The golden-hued bauble had bursted. The "shops" and the land-boomers had fled afar off, and the village was in gloom. Gaunt men looked hungry-eyed at each other and all seemed to say "vanity of vanities; the world is full of wind!" Then at length he awoke, and oh! blessed wakening. Once more he shook his sides for joy that he lived and had his being in the slow, but sure, little burg of Maynard!

To return to the ridicule of neighboring editors. The banter offered by Editor Peterson of The Sumner Journal was certainly of a more practical aspect than that which had come from Maynard. To quote, in part: ${ }^{55}$

Oelwein has at last decided to do something to boom their town, and it is about time, for as one of their citizens remarked there are more vacant houses in Oelwein this spring than ever before ... They have hired two professional town-boomers to come there and boom the town and the only thing they have in the way of inducement is that maybe the Great Western will locate the shops there.

Now do you suppose for a minute that St. Paul is going to let those shops go? No. They will turn around and boycott the road if they do, and in one year they can knock more business out of this road than they will make in that little bonus Oelwein will offer them.

It is a great scheme but every one knows the fate of these boom towns you can find all over the West.

Fully disgusted with the above jeer, Woodruff retorted:

Why do the heathen rage? ... We think this statement should be taken with a good deal of allowance, as we do not think that any of our citizens would disparage their home town with a statement they know to be untrue.

${ }^{65}$ The Sumner Journal, Apr. 12, 1894, quoted in The Oelwein Register, Apr. 19, 1894. 
Even if the town had hired "two professional town-boomers" it is more than Sumner could do or has the enterprise to undertake .. . Of course, if the Railway Company had only thought of moving the shops to Sumner, St. Paul would have been very glad to have let them go; but when the Company seeks to locate them in a live, go-ahead town like Oelwein, of course, in the mind of The Sumner Journal editor, it is an impossibility and St. Paul will hang on to them with a death clutch.

The Oelwein editor closed by chiding the Sumner journalist:

Get off your green goggles of jealousy Brother Peterson. Open your eyes about you and rejoice in the good fortune of your neighbors and that one Iowa town at least has the spirit of progress and advancement-even if it does leave Sumner in the soup!

Thus we have had a glimpse of the activities of the Oelwein businessmen of '94. They succeeded in securing the "Great Western" shops. The actual erection of the shops, including their financing by the Oelwein Land Company, is another story. In closing, the writer would like to quote a poem written upon occasion of the formal opening of the building in which we are now gatheredHotel Mealey. This took place on the evening of Monday, February 21, 1898. Other than the laying of the foundations nothing had been done toward the erection of the shop buildings at that time. In making the main address that evening President Stickney announced that the shops would definitely be built during the year 1898. Mary H. Millard, now Mrs. Burke of Boone, Iowa, was present and was quite impressed by the announcement. She writes: "The coming of the C. G. W. shops was a great event and caused a great sensation. My enthusiasm was so great that I burst forth in a poem which I called 'Oelwein's Glory'." ${ }_{56}$ Her poem appeared in The Oelwein Register, March 9, 1898, and again on March 16, 1898. It reads as follows:

5\% Mary Millard Burke, letter to author, July 20, 1942. 


\section{OELWEIN'S GLORY}

"'Twas the opening night at the 'Mealey,'

A grand, fine, new hotel-

Some four hundred guests were present In costumes rich and swell.

No great event in history

(As I can now recall)

Had caused such wide preparation, As this one of the ball.

For weeks before the grand affair, Maidens' speculation

Had been in gowns of silk and lace

To wear on this occasion.

Matrons and dames of high degree, And daughters young and fair,

Fathers, husbands, and lovers gay, Thronged the corridors there.

'Midst the strains of sweetest music, And scent of flowers rare,

Laughter, and smiles, and brilliant wit

Abounded everywhere.

But sure as night does follow day, In this great world of ours,

So clouds will fling their robes around

Brightest, fairest, bowers.

For lo! without a warning note,

Like ripple on the air,

The bright electric lights go out

And gloom is everywhere.

But soon through the shadowy darkness,

Cast by lamp light's ray,

A manly form advances, sure,

To drive the gloom away.

As step by step he mounts the stair,

Up to the landing place,

We see the shining star of hope

Upon his quiet face.

And who is he, this quiet man;

This man with placid brow?

And why does the crowd loudly cheer

As he moves forward now? 
He is Oelwein's greatest captain;

The leader of her craft.

And thousands upon ten thousands

He heaps upon her raft.

He's A. B. Stickney, President Of the 'Great Western Road.'

He has made the town of Oelwein

The system's central abode.

Four years ago he made his plans

To build vast shops around.

This enterprise would bring good folks

To live in Oelwein's bounds.

And now, as if to seal their faith,

He comes with kindly grace,

A noble light is in his eye,

A smile upon his face.

Firmly he steps to the speaker's stand, His perfect plans to trace.

He tells them all that in a year,

Town to city must give place.

Cheer upon cheer, and cheering still,

Resounds along the way.

No need of bright electric lights,

For night is turned to day.

Long live the noble president

Of western railroad fame!

And well may Oelwein's sterling men

Pay honor to his name,

For in the years that are to come,

Oft' we'll tell the story:

How A. B. Stickney laid the road

That led to Oelwein's glory."

- James Thomas Craig, formerly instructor in the Oelwein, Iowa, high school, received his $M$. A. in American History from Washington University, St. Louis, Mo., in 1941; in 19.42, taught history at Northwestern Military and Naval Academy, Lake Geneva, Wis.; trans- 
ferred to Muskegon, Mich., high school for teaching of history. In 1940-41 he was treasurer of the Historical Association of Greater St. Louis, Mo. Long active in historical work in Iowa and elsewhere. 
Copyright of Annals of Iowa is the property of State of Iowa, by \& through the State Historical Society of Iowa and its content may not be copied or emailed to multiple sites or posted to a listserv without the copyright holder's express written permission. However, users may print, download, or email articles for individual use. 